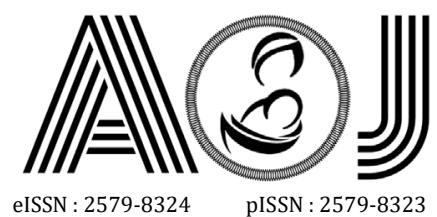

eISSN : 2579-8324
pISSN : 2579-8323

\title{
Inferior Vena Caval Syndrom in Paraaortic Metastastic Lession of Ovarian Dysgerminoma in Pregnancy Manage with Chemotherapy : a Case Report
}

\author{
Madona Utami Dewi ${ }^{1}$, Syamel Muhammad ${ }^{2}$
}

Affiliations : 1. Resident of Obstetrics and Gynecology, Faculty of Medicine, Andalas University, Dr. M. Djamil Central General Hospital Padang; 2. Sub Division of Gynecological Oncology, Obstetrics and Gynecology Department, Faculty of Medicine, Andalas University, Dr. M. Djamil Central General Hospital Padang

Correspondence: Madona Utami Dewi, email : madonaelektris@gmail.com, Hp:085356365023

\begin{abstract}
Background : Inferior caval syndrom is a rare case. It can caused by compresssion of the tumor mass and paraaortic metastastasis lession of ovarian dysgerminoma. Dysgerminoma is one of the most common germ cell tumor, approximately 3-5\% of all ovarian cancers.1 Rate of dysgerminoma metastasis to lymph node is around $28 \%$. In all type of germ cell, dysgerminoma has higher insidens to lymph node metastasis compare to the others. The first level of lymph node metastsis is paraaortic lymph node. However, the insidens is unknown because there is no research about it yet.2,3 Dysgerminoma frequently in young age, less then 30 years. The exact etiology of dysgerminomas has not been determined, although recent molecular studies have implicated loss function of potential tumor suppressor gene TRC8/RNF139, abnormality of Y chromosome and gonadal dysgenesis. 4 The problem arises when dysgerminoma is diagnosed in pregnancy woman as clinically has inferior vena cava syndrom sign and symptoms which acquired efective and fast management.
\end{abstract}

Objective : Discuss inferior caval syndrom as effect of compression by tumor mass, metastasis tumor lesion and chemotherapy management in dysgerminoma with pregnancy

Case Report : Patient 32 years old admitted to M. Djamil central general hospital referred from Batusangkar hospital with diagnosis G3P2A0L2 25-26 weeks of preterm pregnancy + dysgerminoma + obs. Dyspnue. Patient has symptoms dispnue, exercise intolerance, oedem extremity. Physical examination : blood pressure was 100/70 mmHg, HR 120 dpm, RR 35 bpm, T 37 C. Abdomen : uterus fundal was palpated 2 fingers above umbilical, ballotement (+), FHR 150-158 bpm. Genitalia : I V/U normal, vaginal bleeding (-), oedem extremity $+/+$. From ultrasonography found dysgerminoma ovary with compression to inferior vena cava and paraaortic metastatic. Patient was diagnosed with dispnue ec. inferior vena cava syndrom caused by compression of tumor mass + paraaortic lymph node metastasis lession of ovarian dysgerminoma on G3P2A0L2 25-26 weeks of preterm pregnancy. Patient was managed by BEP chemotherapy and symptom was dissapeared. Patient was admitted to M. Djamil again with 34-35 weeks of preterm pregnancy in active phase of first stage. Because obtructed of labor patient was decide to performed LSCS. Female baby was born 1800 gram, baby's length was $45 \mathrm{~cm}$, $A / S 7 / 8$, there is no congenital anomaly. Patient was followed up 1 month after surgery, there is no symptoms, but fromUltrasonograhy found corpus metastasis and CT scan impressed paraaortic lymph node metastasis + copus metastasis. Chemotherapy was continue one month after caesarean section. She was completed 4 cycles chemothrapy and the disease was cureable. 


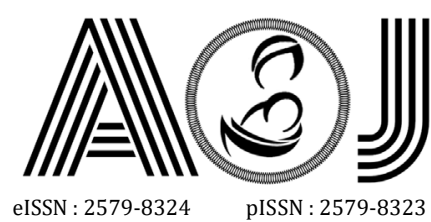

eISSN : 2579-8324
pISSN : 2579-8323
ANDALAS OBSTETRICS AND GYNECOLOGY JOURNAL

Alamat Korespondensi:

Ruang Redaksi Andalas Obstetrics and Gynecology Journal, Lantai 3 PPDS Obstetri dan Ginekologi Universitas Andalas, RSUP DR. M. Djamil Padang, Jl. Perintis Kemerdekaan Padang, Sumatera Barat 25127

Website:

http://jurnalobgin.fk.unand.ac.id/index.php/JOE

Conclusion : Caval syndrom is a rare case and fatal, caused by direct compression of dysgerminoma mass and paraaortic lymph node metastasis. Diagnosis of dysgerminoma is anatomy pathology diagnose. Management of dysgerminoma is surgical staging and 3-4 cycle of chemoterapy with BEP regimen. Chemoterapy with BEP (Bleomisin-Etopuside-Cisplatin) is safe to performed at second trimester with inferior vena cava syndrom ec paraaorta lymph nodes metastasis. Dysgerminoma has a good response to chemotherapy with survival rate $96 \%$

Keywords: Caval syndrom, lymph node paraaortic metastatic

\section{INTRODUCTION}

Inferior vena cava syndrome is a rare and fatal case, one of the causes is the suppression of tumor mass that metastasizes to the paraaortic lymph nodes that can originate from malignancies in the ovary. ${ }^{1}$ Dysgerminoma is the most ovarian germ cell tumor type, about 3$5 \%$ of the whole ovarian malignancy. The incidence of metastatic dysgerminoma to KGB is $28 \%$, of all ovarian germ cell tumors of dysgerminoma most often metastasize to KGB. The first KGB of metastatic dysgerminoma is the paraaortic KGB. However, the apparent incidence is unknown due to the absence of research on dysgerminoma metastasians. ${ }^{2,3}$

Dysgerminoma is common at a young age, age $<30$ years.4 Data on pregnant dysgerminoma patients is not large, a study conducted by Satoshi et al in 105 patients who were followed for an average of 10.4 years found 42 out of 45 patients who wanted children successfully were pregnant, the total number of pregnancies were 65 and 56 babies were born in 40 dysgerminoma patients. ${ }^{5}$ From data published by AJOG, 2018 more than $90 \%$ of dysgerminoma patients aged $<40$ years who got Fertility Sparing Treatment (FST) with the desire to get pregnant successfully were pregnant and giving birth. ${ }^{5}$

Etiology is definitely unknown, molecularly it is caused by the loss of function of the TRC 8 / RNF 139 tumor suppressor gene, Y chromosome abnormalities and gonadal dysgenesis. ${ }^{4}$

Problems arise when dysgerminoma occur in pregnant women and must be managed with chemotherapy. The controversial effects of chemotherapy on fetal growth and the incidence of venous cava syndrome due to suppression by tumor mass and metastatic dysgerminoma to the paraaortic KGB are very rarely found became the background by the writer to raise this case as a national scientific case report.

\section{CASE REPORT}

A 32-year-old woman came to the ER RSUP dr. M Djamil Padang referral from Batusangkar Regional Hospital with diagnosis of gravid preterm G3P2AOH2 25-26 weeks + dysgerminoma + obs. Dispnue. The patient complained of shortness of breath, fatigue and swollen feet. From physical examination it was found TD 100/70 mmHg, HR 120x / min, RR 35x / min, T 37 C. Abdomen: FUT palpable 2 fingers above the center, ballottement (+), DJJ 150-158x / minute. Genitalia: I / V calm U, PPV (-), Extremities edema + / +. 


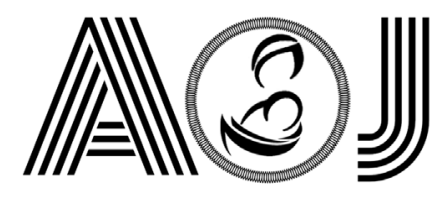

eISSN : 2579-8324

Ruang Redaksi Andalas Obstetrics and Gynecology Journal, Lantai 3 PPDS Obstetri dan Ginekologi Universitas Andalas, RSUP DR. M. Djamil Padang, Jl. Perintis Kemerdekaan Padang, Sumatera Barat 25127

\section{Website:}

http://jurnalobgin.fk.unand.ac.id/index.php/JOE

From an ultrasound examination :

- The uterus appeared to be pushed to the right, gravid 25-26 weeks

- An anterior uterine mass and a $7.7 \mathrm{~cm}$ vesica with hyperechoic inhomogeneous appearance

- an overview of an irregular hyperechoic mass measuring $15.74 \mathrm{~cm} \times 15.19 \mathrm{~cm}$ extending to the left hypochondria pressing the left kidney to the superior and sticky base mass in the abdominal aorta and pressing inferior vena cava

- Left and right kidney appeared widening colic.

- Gravid + residual ovarian malignant tumor with inferior vena cava suppression + paraoarta metastasis
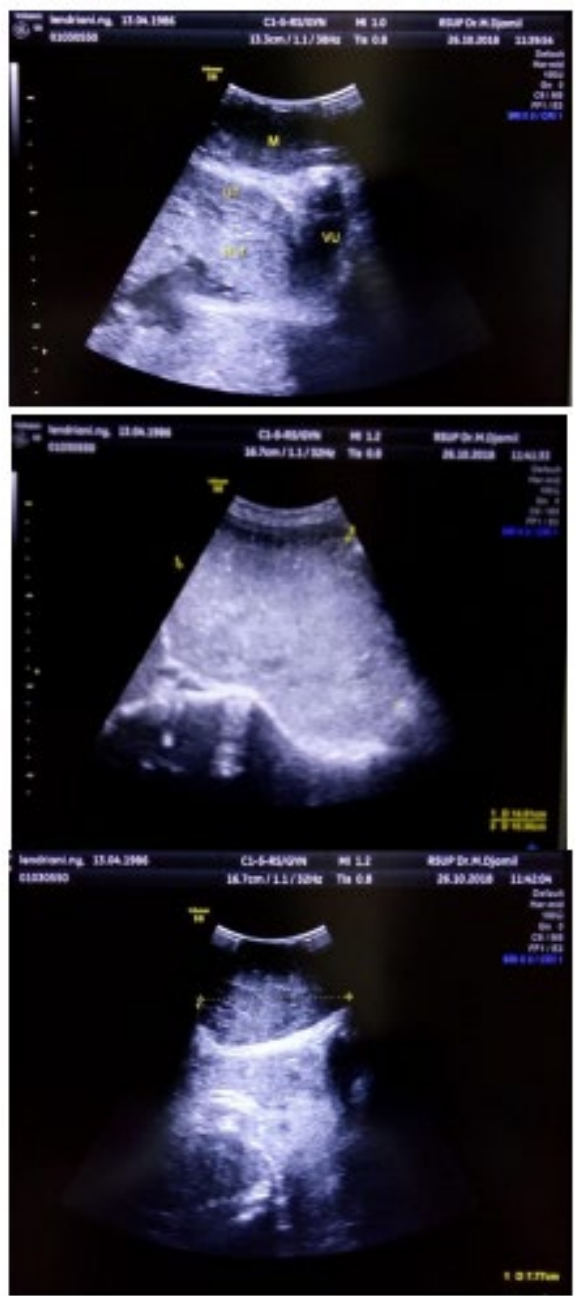

Figure 1. A mass in the anterior uterus 


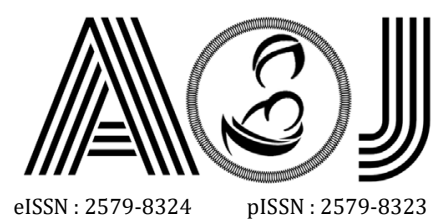

Ruang Redaksi Andalas Obstetrics and Gynecology Journal, Lantai 3 PPDS Obstetri dan Ginekologi Universitas Andalas, RSUP DR. M. Djamil Padang, Jl. Perintis Kemerdekaan Padang, Sumatera Barat 25127

\section{Website:}

http://jurnalobgin.fk.unand.ac.id/index.php/JOE

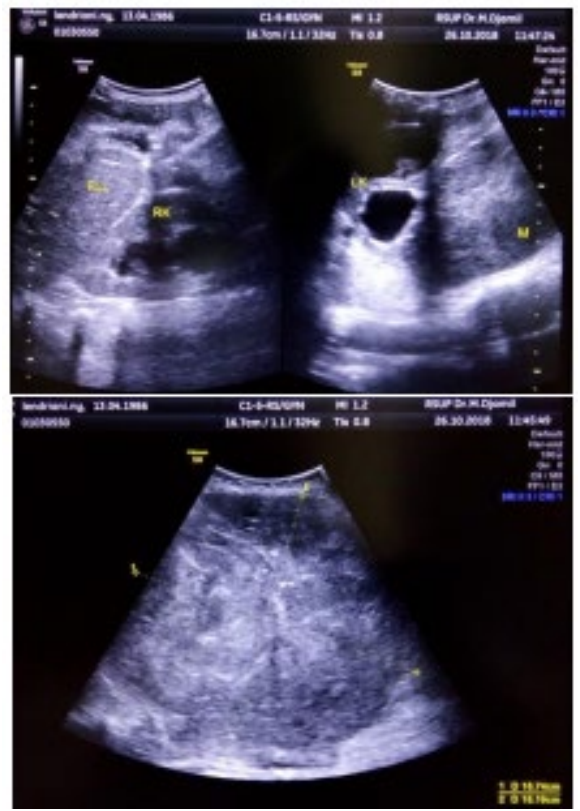

Figure 2. USG : residual ovarian tumor measuring $15.77 \times 15.19 \mathrm{~cm}$

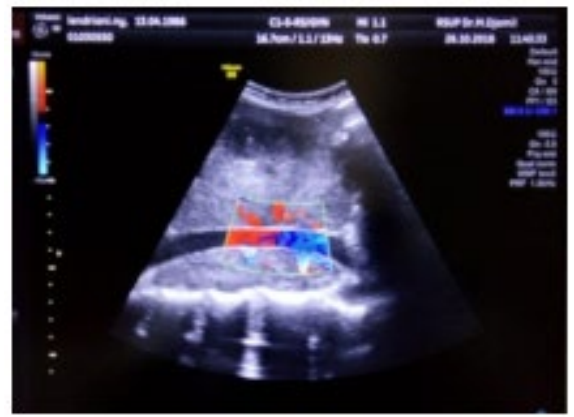

Figure 3. Inferior Vein Suppression by tumor mass

The patient was diagnosed with inferior vena cava syndrome ec tumor compression + metastasis dysgerminoma to KGB Para aorta at G3P2AOH2 gravid preterm 25-26 weeks. The patient was given BEP chemotherapy. After 2x chemotherapy, clinical complaints improved. The patient returned to the hospital at 34-35 weeks of pregnancy with the complaint of inpartu, his 3-4x / 40 / K, DJJ 150-1 159, opening 7-8 cm, amniotic fluid (-) remaining clear. Due to the indication of obstetric then the patient performed SCTPP born a baby girl weighing 1800 grams, PB $45 \mathrm{~cm}, \mathrm{~A} / \mathrm{S} 7 / 8$, found no congenital abnormalities and signs of IUGR in the baby.

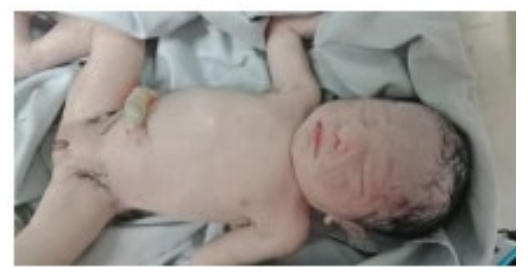

Figure 4. Baby of Mrs.L 


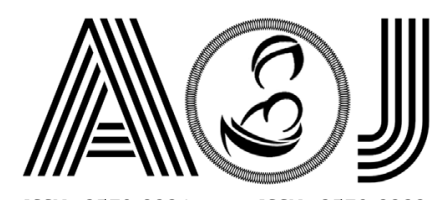

eISSN : 2579-8324

Ruang Redaksi Andalas Obstetrics and Gynecology Journal, Lantai 3 PPDS Obstetri dan Ginekologi Universitas Andalas, RSUP DR. M. Djamil Padang, Jl. Perintis Kemerdekaan Padang, Sumatera Barat 25127

\section{Website:}

http://jurnalobgin.fk.unand.ac.id/index.php/JOE

Exploration of the uterus and both ovaries was performed. The right ovary appeared to be of normal size and the left ovary cannot be identified (post salpingectomy sinistra).

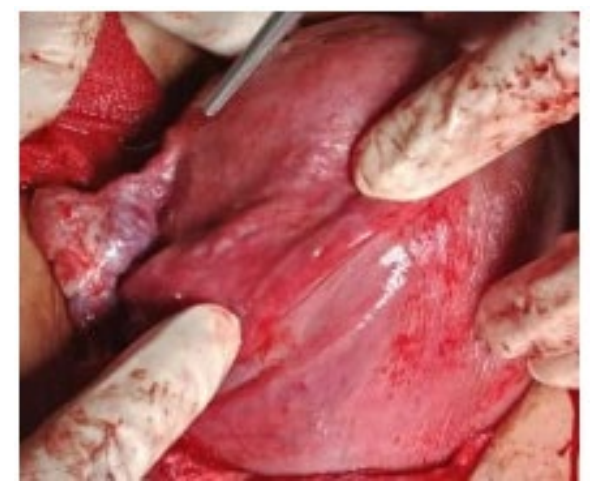

Figure 5. Right ovary

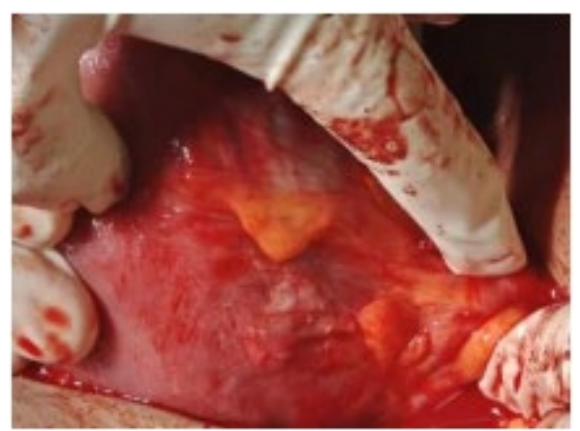

Figure 6. Location of the left ovary that has already experienced salpingectomy

Follow-up 1 month post delivery there was no complaint, but from CT scans it was found paraaortic KGB metastases. 


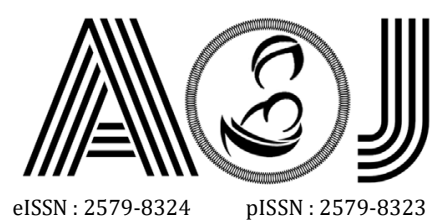

eISSN : 2579-8324

Ruang Redaksi Andalas Obstetrics and Gynecology Journal, Lantai 3 PPDS Obstetri dan Ginekologi Universitas Andalas, RSUP DR. M. Djamil Padang, Jl. Perintis Kemerdekaan Padang, Sumatera Barat 25127

http://jurnalobgin.fk.unand.ac.id/index.php/JOE
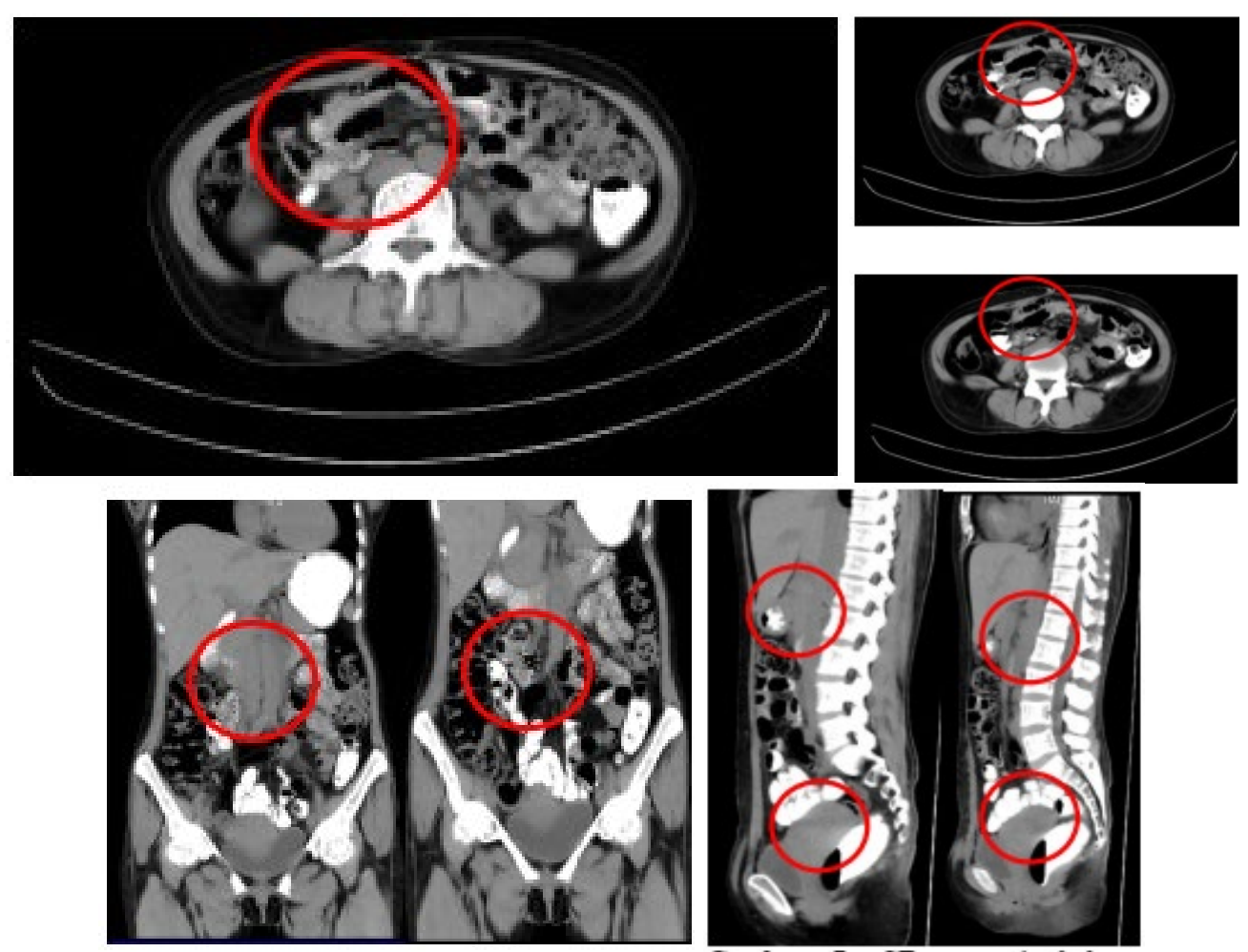

Figure 7. CT scan 1 month postpartum (post chemo $2 x$ ) After 1 month postpartum continued with the administration of chemotherapy to 3 and 4

\section{DISCUSSION}

\section{Inferior Vena Cava Syndrome}

Inferior vena cava syndrome is a rare and fatal case, usually caused by iatrogenic such as surgical procedures involving venous cava, other causes may be due to venous infection, thrombosis, congenital obstruction as in Budd-Chiari Syndrome, or due to external compression by a tumor mass, aneurysms and so on. ${ }^{1}$

The incidence of inferior vena cava syndrome caused by the suppression of dysgerminoma is unknown because this case is very rare. ${ }^{1}$

The inferior vena cava is the largest retroperitoneal vein formed from the mouth of the left and right communal iliac veins, anatomically as high as the lumbar $\mathrm{V}$. This blood vessel functions to carry deoxygenated blood from the lower extremity and the back abdomen to the right atrium of the heart. These blood vessels do not have valves, blood flow back to the right atrium of the heart occurs due to differences in pressure produced by respiratory movements. ${ }^{6}$ 


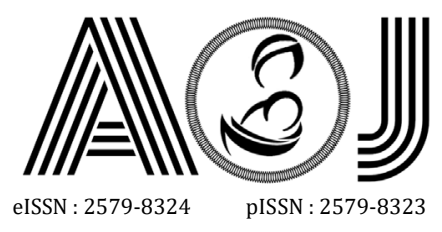

Ruang Redaksi Andalas Obstetrics and Gynecology Journal, Lantai 3 PPDS Obstetri dan Ginekologi Universitas Andalas, RSUP DR. M. Djamil Padang, Jl. Perintis Kemerdekaan Padang, Sumatera Barat 25127

\section{Website:}

http://jurnalobgin.fk.unand.ac.id/index.php/JOE

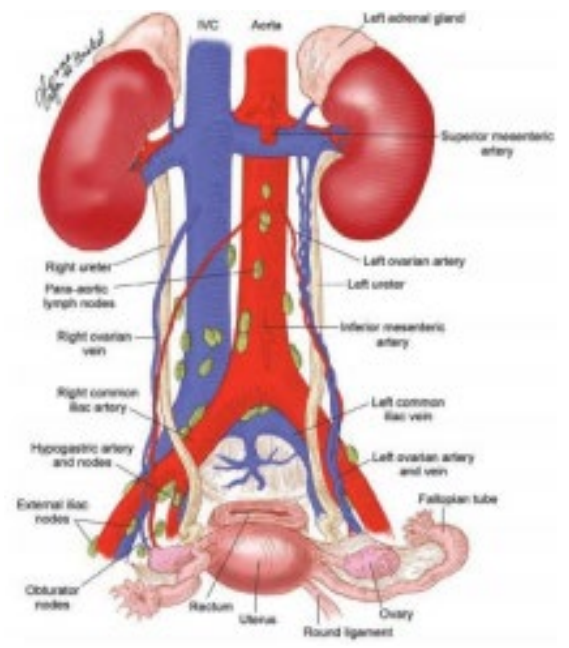

Figure 8. Inferior vena cava and para aorta $\mathrm{KGB}^{7}$

Clinical symptoms depend on the level of obstruction and the development of collateral venous blood flow. Symptoms that arise include shortness of breath, edema of the extremities, fatigue, varicose veins, symptoms of liver congestion, renal insufficiency with proteinuria. $^{1}$

If the blood flow back to the heart and with a little amount then this will cause a decrease in cardiac output which will occur tachycardia, decreased stroke volume, hypotension, vertigo, syncope, even sudden death. ${ }^{1}$

\section{Dysgerminoma}

Dysgerminoma are the largest group of germ cell tumors, around 1-3\% of all ovarian malignancies. $75 \%$ occur at the age of $10-30$ years, $5 \%$ occur at the age of less than 10 years and rarely occur at the age of 50 years. About $5 \%$ of dysgerminoma occur in the phenotype of women with abnormal gonads. ${ }^{7,8}$

Etiology is definitely unknown, but it is molecularly caused by the loss of function of the TRC 8 / RNF tumor suppressor gene 139. ${ }^{4}$ Other causes of dysgerminoma are associated with $\mathrm{Y}$ chromosome abnormalities, 46XY, gonadal digenesis, mixed gonadal digenesis and reduced expression of the $16 \mathrm{p}$ protein gene due to the process of methylation by INK4 stimulating proliferation cell. However, $95 \%$ of women with dysgerminoma are genetically normal. ${ }^{8,9}$

The incidence of ovarian tumors in pregnancy is 1 in 1000 pregnancies. While the incidence of ovarian cancer in pregnancy is even lower at 1 in 12,500-25,000 pregnancies. ${ }^{9}$ $20-30 \%$ of ovarian malignancies associated with pregnancy are dysgerminomas. ${ }^{7}$

The clinical symptoms of dysgerminoma are usually asymptomatic. It is usually detected accidentally during an USG. Symptoms that may occur are abdominal pain, palpable mass in the pelvis, compression symptoms from tumor masses such as frequent urination, dysuria, and bowel obstruction. ${ }^{9}$ 


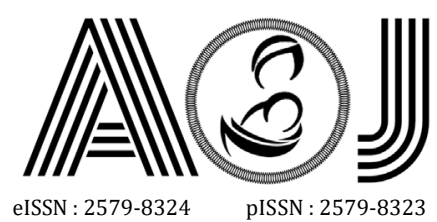

eISSN : 2579-8324
pISSN : 2579-8323
ANDALAS OBSTETRICS AND GYNECOLOGY JOURNAL

Alamat Korespondensi:

Ruang Redaksi Andalas Obstetrics and Gynecology Journal, Lantai 3 PPDS Obstetri dan Ginekologi Universitas Andalas, RSUP DR. M. Djamil Padang, Jl. Perintis Kemerdekaan Padang, Sumatera Barat 25127

Website:

http://jurnalobgin.fk.unand.ac.id/index.php/JOE

Investigations: USG, tumor markers for dysgerminoma are lactate dehydrogenase (LDH), alpha- fetoprotein (AFP), and beta-human chorionic gonadotropin (beta-hCG), MRI, and CT scan. ${ }^{10,11}$

There are several USG images that show ovarian malignancies, including size, solid components, heterogeneous, papil, internal septum, bilateral, irregular edges increase in vascularity, low resistance to blood flow, and the presence of ascites. MRI can provide additional information. CT scan is not recommended in pregnancy because of the risk of radiation that interferes with fetal development. ${ }^{10}$

Alpha- fetoprotein (AFP) is a normal fetal serum protein that is synthesized by the liver, yolk sac, and gastrointestinal tract. Normal levels of AFP during pregnancy are 1,000-10,000 $\mathrm{ng} / \mathrm{ml}$. AFP $100 \%$ is found in women with yolk sac tumors, $61.9 \%$ in immature teratoma, and $11.8 \%$ in dysgerminomas. ${ }^{10,11}$

Human chorionic gonadotropin (hCG) is a glycoprotein produced by syncytiotrophoblast. Lactate dehydrogenase (LDH) - dysgerminoma generally increases in $\mathrm{LDH}$. The role of tumor markers in pregnancy has limitations because physiologically during fetal development there is an increase in AFP, LDH, and hCG. ${ }^{10,11}$

Dysgerminoma images on CT scan in the form of a solid mass, multilobus, with the focus of calcification in the middle. ${ }^{12}$

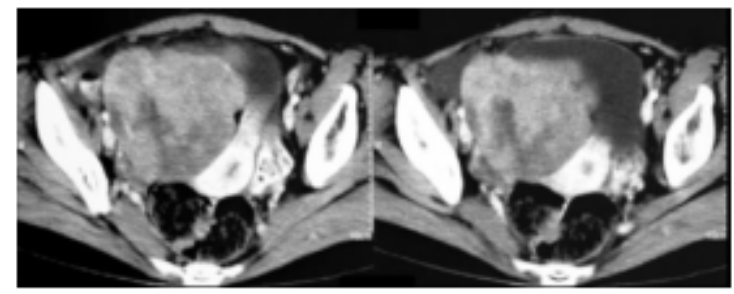

Figure 9. Pelvic CT scan shows a picture of irregular heterogeneous mass originating from the left adnexa with upward enlargement. The uterus is out of position due to mass pressure ${ }^{12}$

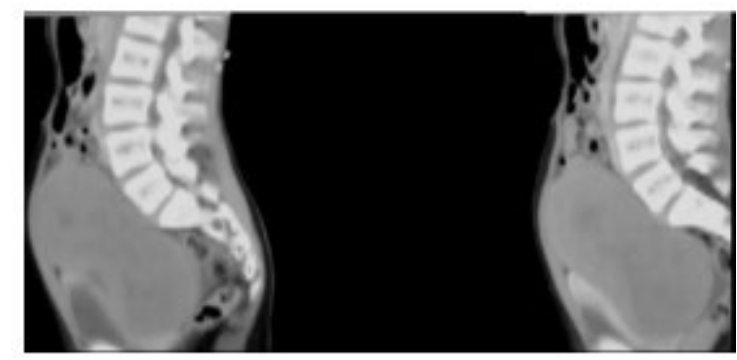

Figure 10. The sagittal section of the CT scan shows a pelvic mass that results in the vesica and uterus not being positioned ${ }^{12}$ 


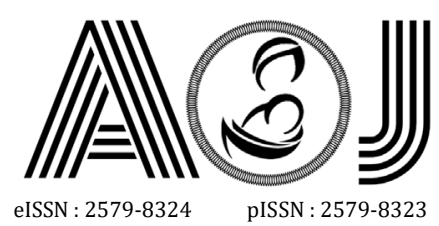

eISSN : 2579-8324
pISSN : 2579-8323

Ruang Redaksi Andalas Obstetrics and Gynecology Journal, Lantai 3 PPDS Obstetri dan Ginekologi Universitas Andalas, RSUP DR. M. Djamil Padang, Jl. Perintis Kemerdekaan Padang, Sumatera Barat 25127

\section{Website:}

http://jurnalobgin.fk.unand.ac.id/index.php/JOE

Staging dysgerminoma based on FIGO is as follows ${ }^{13}$

Table 1. FIGO Ovarian Cancer Staging

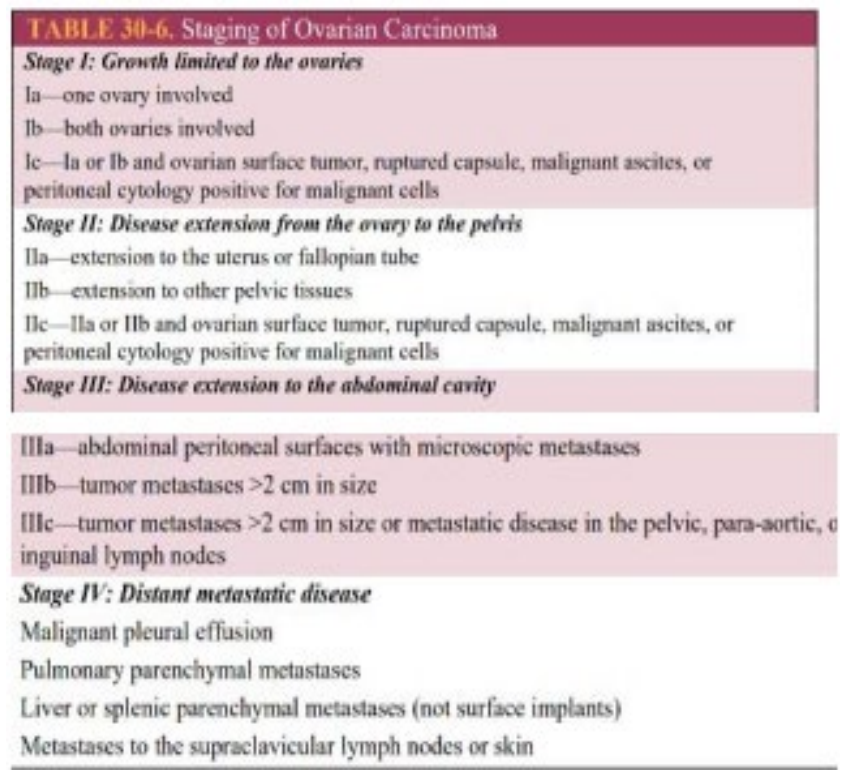

The stage of dysgerminoma is determined based on surgical staging. Preoperative patient with suspected malignancy performed midline abdominal incisions to access to the upper abdomen. Ovarian tumors should be removed intact if possible and a frozen section is performed. If the pathology results are proven to be malignant and originate from the ovary then surgical staging must be performed by taking the following sample: 7,13

1. Free fluid especially on the cavum douglas taken for cytological examination

2. If there is no free fluid, peritoneal washing is done with 50-100 cc of saline in the area of cavum Douglas, paracolic and below hemidiaphragm cavities.

3. Systematic exploration of the entire abdominal and visceral cavity

4. 4) Suspected area or adhesion on the surface of the peritoneum taken for biopsy

5. Diaphragm biopsy for cytology smear

6. Infrasonic omentectomy

7. KGB pelvis

8. KGB Para aorta

The incidence of metastatic dysgerminoma to KGB is $28 \%$, of all ovarian germ cell tumors of dysgerminoma most often metastasize to KGB. The first KGB level for metastatic dysgerminoma is paraaortic KGB. ${ }^{3}$ The first evaluation is on preoperative examination and the second is on intraoperative palpation. If nodal sentinel dissection is performed, pay attention to how much KGB is colored therefore it determines the KGB that must be removed. KGB was biopsied in several areas where lymphadenectomy was suspected. Now MRI and CT scan were 


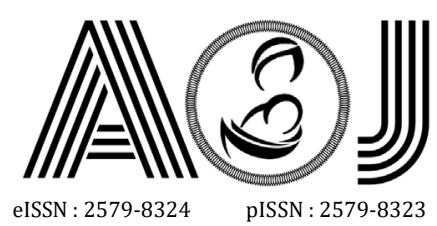

eISSN : 2579-8324
pISSN : 2579-8323

Ruang Redaksi Andalas Obstetrics and Gynecology Journal, Lantai 3 PPDS Obstetri dan Ginekologi Universitas Andalas, RSUP DR. M. Djamil Padang, Jl. Perintis Kemerdekaan Padang, Sumatera Barat 25127

\section{Website:}

http://jurnalobgin.fk.unand.ac.id/index.php/JOE

useful methods for evaluating GBS and the development of preoperative and postoperative tumors. ${ }^{2}$

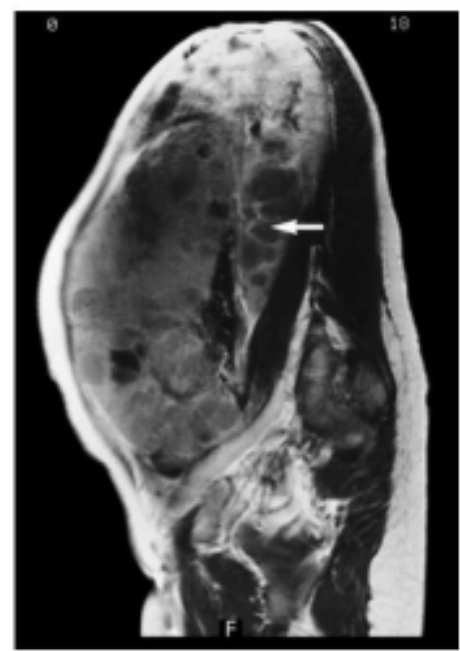

Figure 11. Overview of description of para aorta KGB enlargement 2
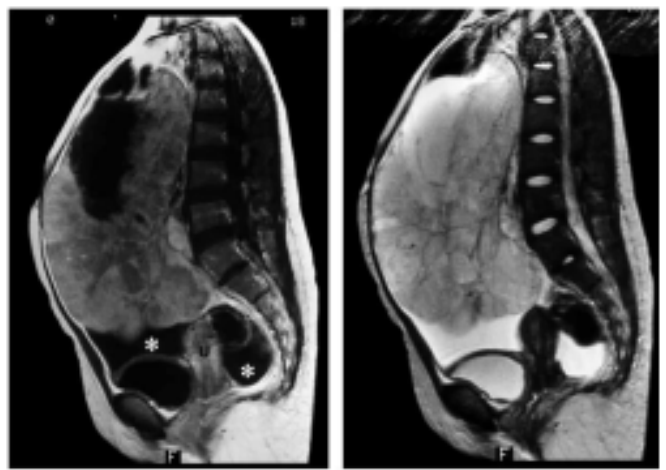

Figure 12. Overview of MRI of tumors with focal necrosis and $\left({ }^{*}\right)$ ascites 2

About $65 \%$ of dysgerminoma were diagnosed in early stadium (stage I). $85 \%-90 \%$ of stage I tumors were located in one ovary, while $5-10 \%$ occurred in both ovaries. In patients where the contralateral ovary was maintained, dysgerminoma can develop $5-10 \%$ in the contralateral ovary within 2 years later, if not getting chemotherapy. ${ }^{7}$

In $25 \%$ of patients with metastasis, the spread most often occurs through lymphatic flow. The KGB most often discovered by metastasis is the KGB para aorta. Dysgerminoma can also spread hematogenous or directly from the exfoliation of ovarian capsules or cells on the surface of the peritoneum. Metastases to the bones, lungs, liver and brain rarely occur only in recurrent disease. While metastases to the mediastinum and supraclavicular GBS are usually manifestations of advanced disease. ${ }^{7}$

Management of patients with early-stage dysgerminoma is surgery, including resection of primary lesions and limited surgical staging; washing, omentum biopsy, careful touch on the entire surface of the retroperitoneal KGB peritoneum, and biopsy on all those suspected. 


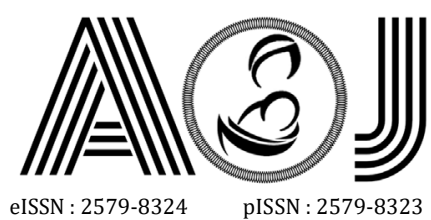

eISSN : 2579-8324
pISSN : 2579-8323
ANDALAS OBSTETRICS AND GYNECOLOGY JOURNAL

Alamat Korespondensi:

Ruang Redaksi Andalas Obstetrics and Gynecology Journal, Lantai 3 PPDS Obstetri dan Ginekologi Universitas Andalas, RSUP DR. M. Djamil Padang, Jl. Perintis Kemerdekaan Padang, Sumatera Barat 25127

Website:

http://jurnalobgin.fk.unand.ac.id/index.php/JOE

Chemotherapy is given to patients with metastasis. Because dysgerminoma is common in young women, special consideration for maintaining fertility must be given. ${ }^{7}$

The minimum surgery for ovarian dysgerminoma is unilateral oophorectomy. If there is a desire to maintain fertility, the contralateral ovaries, fallopian tubes and uterus must be abandoned even if there are metastases, because these tumors are very sensitive to chemotherapy. If fertility is no longer needed, it is more appropriate to have a total hysterectomy and bilateral salpingo oophorectomy in patients with advanced disease. In patients with karyotypes containing the $Y$ chromosome, both ovaries should be removed, although the uterus may remain in place for possible embryo transfer later. It is important not to operate if morbidity is high and if it will delay the initial administration of chemotherapy. ${ }^{7}$

In patients where dysgerminoma is seen from ovarian inspection, staging should be done to determine the possibility of invisible metastases. Dysgerminoma usually metastasize to the paraaortic KGB around the renal vein. Peritoneal rinses are taken for cytological examination, biopsy of the suspected peritoneal surface and pelvic KGB biopsy. ${ }^{7}$

Many patients with dysgerminoma are referred after unilateral salpingo-oophorectomy without surgical staging. Management options for this condition include: 1) Laparotomy for surgical staging, 2) Regular CT scan of the pelvic abdomen, 3) Adjuvant chemotherapy.7

There is no need to do a second laparotomy in a patient with dysgerminoma. The role of reoperation in the remaining dysgerminoma is unclear, leaving only more necrotic tissue. Patients only need to be monitored by scanning and tumor markers. ${ }^{7}$

Although recurrence is rare, $75 \%$ will occur within 1 year after initial management, the most frequent location in the peritoneal space and the pelvic nodes. These patients must be treated with chemotherapy or radiation, depending on the location of the tumor and previous management. If the patient was previously only operated without chemotherapy, the patient is given chemotherapy, if the patient has been given chemotherapy with the previous BEP regimen, then other regimens such as TIP (paclitaxel, ifosfamide, and Cisplatin can be tried). Radio therapy can be considered in dysgerminoma patients who experience local recurrence, but fertility cannot be maintained if the patient receives radiation. ${ }^{7}$

Because dysgerminoma tends to occur in young women, it is often found with pregnancy. If stage IA dysgerminoma is found, the tumor can be completely removed and the pregnancy continued. In patients with advanced stages, continuing pregnancy depends on gestational age. Chemotherapy can be given in trimesters 2 and 3 at the same dose in no pregnant women without causing damage to the fetus. However, there have been reports of congenital malformations in pregnant women receiving chemotherapy. ${ }^{7,14}$

Surgical intervention in the case of ovarian tumors in pregnancy is done if: suspicious of malignancy, acute complications (torsion, rupture), mass size $>5 \mathrm{~cm}$ with a solid component with septum at 18 weeks gestation, tends to increase in size during pregnancy or more than 


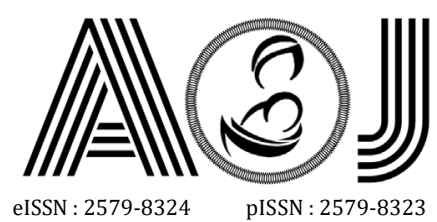

eISSN : 2579-8324
pISSN : 2579-8323

Ruang Redaksi Andalas Obstetrics and Gynecology Journal, Lantai 3 PPDS Obstetri dan Ginekologi Universitas Andalas, RSUP DR. M. Djamil Padang, Jl. Perintis Kemerdekaan Padang, Sumatera Barat 25127

$8 \mathrm{~cm}$. The goal of surgery is to remove the tumor mass to avoid complications in pregnancy. Operate manipulation of the uterus to a minimum because it can lead to placental abruption, preterm labor and IUFD. If the intra op of clinical appearance is low suspicion of malignancy then it is more recommended to perform cystectomy than salpingo-oophorectomy. However, if clinically suspicious of high malignancy (ascites, there is a solid mass) then the tube and ovary must be removed. And frozen section must be done. If it is confirmed to be malignant, surgical staging must be performed. The time for surgical intervention in pregnant women is 14-22 weeks gestation because the function of the corpus luteum has been taken over by the placenta $9,15,16$

The chemotherapy regimen used is the Bleomycin-Etoposide-Cisplatin (BEP) regimen. The procedures for chemotherapy agents to work are divided into 2:1) Non-specific cell cycle: works in all phases of the cell cycle. Bleomycin Example 2) Cell Cycle Specific: works in certain phases in the cell cycle, for example Cisplatin works in the G2 phase (post synthetic phase). The cell cycle is explained in the following figure: ${ }^{7}$

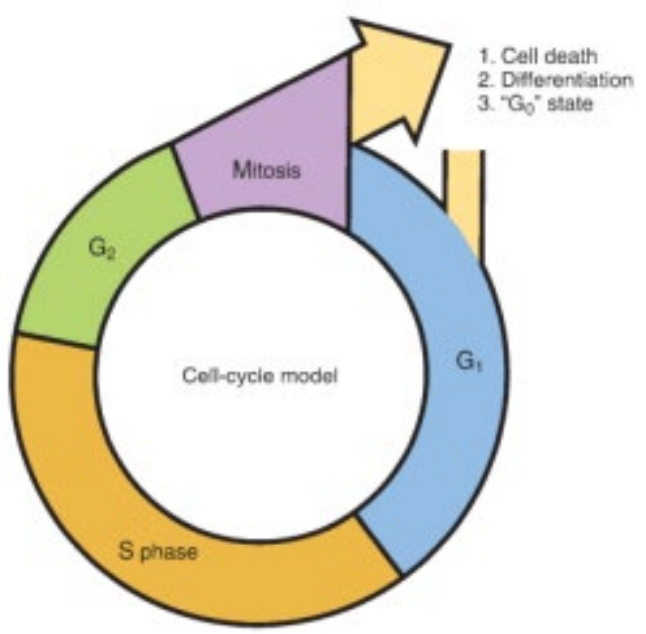

Note $:^{7}$

Figure 13. Cell cycle ${ }^{7}$

- $\mathrm{G} 1$ is the phase of synthesis of enzymes and proteins needed to form DNA / RNA.

- Phase $S$ is the phase of DNA synthesis

- Phase G2 (Post-phase DNA synthesis) where cell diplomer and DNA double-strand occur

- Phase M (mitotic phase) where in this phase cell division occurs

- Phase G0 (resting phase) 


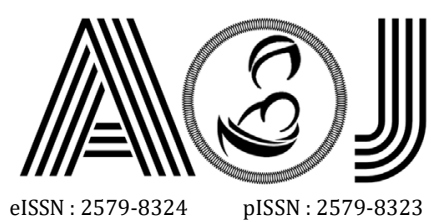

eISSN : 2579-8324
pISSN : 2579-8323

Ruang Redaksi Andalas Obstetrics and Gynecology Journal, Lantai 3 PPDS Obstetri dan Ginekologi Universitas Andalas, RSUP DR. M. Djamil Padang, Jl. Perintis Kemerdekaan Padang, Sumatera Barat 25127

Website:

http://jurnalobgin.fk.unand.ac.id/index.php/JOE

The dosage of chemotherapy agents based on Berek, 2015 is: ${ }^{7}$

\begin{tabular}{|c|c|}
\hline Regimen and Drugs & Dose and Schedule' \\
\hline \multicolumn{2}{|l|}{ BEP } \\
\hline Bleomycin & 30,000 international Units weekly for a total of 12 wks \\
\hline Eloposide & $100 \mathrm{mghm}^{2} / \mathrm{d} \times 5$ d every 3 wks \\
\hline Cisplatin & $20 \mathrm{mg}^{2} / \mathrm{d} \times 5$ d every $3 \mathrm{wks}$ \\
\hline
\end{tabular}

Figure 14. Combined chemotherapy ${ }^{7}$

Bleomycin is an anti-tumor antibiotic chemotherapy agent, isolated from the fungus Streptomyces. This structure contains the bonding of DNA fragments with ion units. This bond produces an antitumor effect by breaking the DNA chain, especially at the location of guanine (in the G2 phase of the cell cycle). This drug is excreted in the urine, and toxic effects are increased in patients with impaired kidney function as the route of intravenous or intramuscular administration. Toxic effect: fever, dermatological reactions, pulmonary toxicity such as interstitial pneumonitis, anaphylactic reaction. ${ }^{7}$

Cisplatin is an alkylating like agent chemotherapy agent. Cisplatin causes the $\mathrm{G} 2$ cell cycle to stop and apoptotic cell death occurs. The route of administration is intravenous. Common toxic effects: nephrotoxic, tinnitus, deafness, nausea, vomiting, myelosuppression and peripheral neuropathy. While etoposide has anxious effects on patients. ${ }^{7}$

Pregnancy with ovarian malignancy is a challenge that requires a balance between providing optimal therapy for the mother and consideration of fetal well-being. ${ }^{9}$

Germ cell tumor is chemosensitivity which means that the administration of chemotherapy is curative. The risk of congenital anomalies due to chemotherapy is highest during the first trimester of pregnancy. At 10 days after conception the cell was still omnipotent and the survival of the embryo depends on the number of cells damaged by the chemotherapy agent. If cells are damaged in large numbers, miscarriages can occur. But if only a few cells are damaged, the embryo can survive without malformation. The organogenesis period starts on the 10th day and finishes on the 8th week. The administration of cytotoxic drugs in this period will result in teratogen effects on the fetus. The heart, neural tubes, extremities, palate and ears most commonly malformed. Depending on the dose and agent used, the possibility of fetal damage can occur. If a single chemotherapy agent is used, the malformation rate is $7-17 \%$, and it increases to $25 \%$ when using a combination chemotherapy agent. By using folic acid, the risk of malformation decreases by up to $6 \% .{ }^{17}$

Thus the administration of chemotherapy is not recommended to be given in the period of organogenesis (trimester I). The administration of chemotherapy in the 2nd and 3rd trimesters is usually not associated with an increased risk of congenital abnormalities, although the number of patients studied is still small. ${ }^{7}$ But there is a risk of preterm labor, 


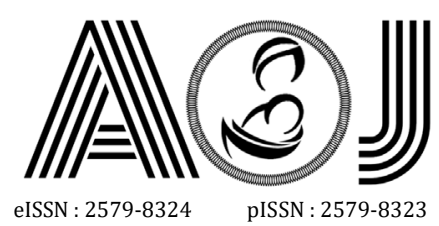

eISSN : 2579-8324
pISSN : 2579-8323

Ruang Redaksi Andalas Obstetrics and Gynecology Journal, Lantai 3 PPDS Obstetri dan Ginekologi Universitas Andalas, RSUP DR. M. Djamil Padang, Jl. Perintis Kemerdekaan Padang, Sumatera Barat 25127

IUGR, IUFD, hematopoietic suppression. Giving chemotherapy 3-4 weeks before delivery should also be avoided because it increases the risk of infection and bleeding during labor. ${ }^{17}$

Physiological changes during pregnancy also cause changes in the pharmacokinetics of chemotherapy drugs ranging from absorption, distribution, metabolism and excretion. Changes in drug metabolism begin at 4 weeks' gestation and continue to increase under the influence of progesterone and estrogen, thereby increasing the toxic effects during pregnancy. Increased drug absorption increases due to changes in gastric acid secretion and intestinal motility. ${ }^{7}$

The effect of pregnancy on ovarian tumors is torsion, incarceration, rupture, bleeding during pregnancy. While the influence of ovarian tumors on IUFD pregnancy is reported in $25 \%$ of cases. $^{10,18}$

Algorithm in the management of dysgerminoma in pregnancy:

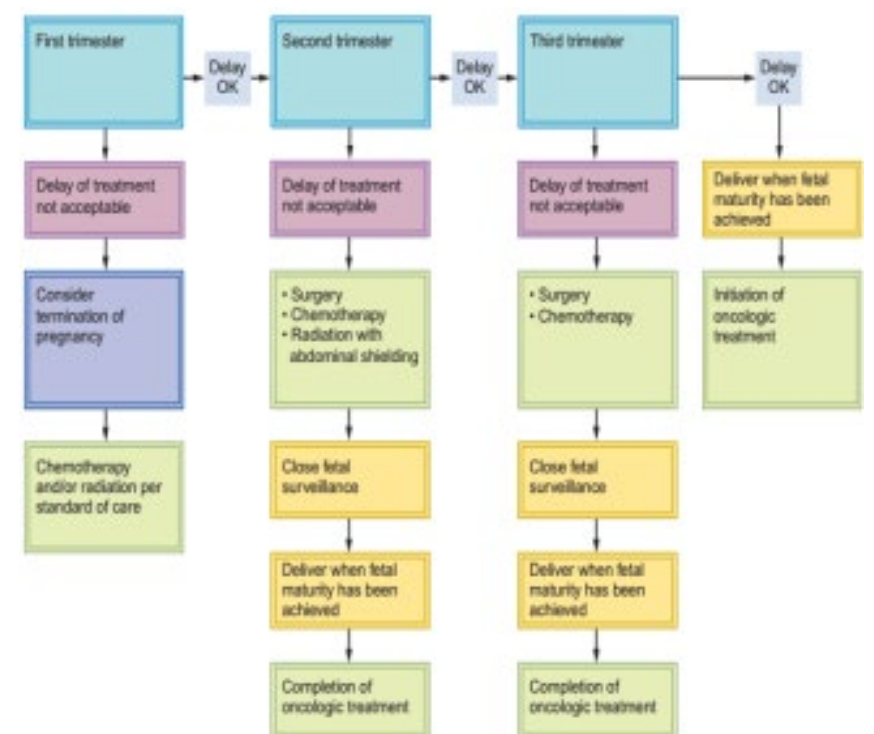

Figure 15. Chemotherapy algorithm in pregnancy ${ }^{7}$

Recurrent dysgerminoma often occurs 2-3 years after completion of treatment. Therefore follow-up observation and physical examination every 3-4 months in the first 3 years, every 6 months in the 4th and 5th years, and every year is recommended. ${ }^{10,18,19,20}$

In this case the patient was diagnosed with dysgerminoma at the age of 28 years, according to the literature which states that $75 \%$ of dysgerminoma occur at the age of $10-30$ years. The diagnosis of dysgerminoma is obtained from the results of anatomic pathology. ${ }^{7}$

The patient lost control and 4 years later came in 25-26 weeks pregnant with complaints of shortness of breath, edema feet, fatigue, tachycardia and enlarged abdomen beyond gestational age, ultrasound showed there was an ovarian tumor mass size of $15.77 \times 15.19$ $\mathrm{cm}$, there was an image of vascular cava suppression by tumor mass and tumor metaation to the paraaortic lymph nodes. The patient was diagnosed with gravid + inferior vena cava syndrome ec suppression of mass + metastatic dysgerminoma to paraaortic KGB. 


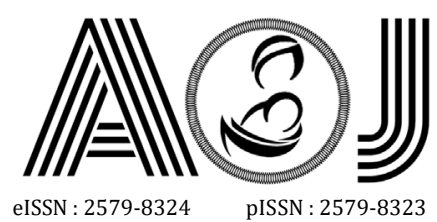

eISSN : 2579-8324

pISSN : 2579-8323

Ruang Redaksi Andalas Obstetrics and Gynecology Journal, Lantai 3 PPDS Obstetri dan Ginekologi Universitas Andalas, RSUP DR. M. Djamil Padang, Jl. Perintis Kemerdekaan Padang, Sumatera Barat 25127

Inferior vena cava syndrome in the patient wass caused by suppression by tumor mass and paraaortic KGB metastases. Vein walls were thin because they did not have intimate tunica as well as the aorta causing these vessels to be easily compressed resulting in stasis. In addition, inferior vena cava is different from other veins where these vessels do not have valves thus the backflow relies only on the movement of the diaphragm during breathing. When there is a tumor mass that presses down to the left hypochondria it will block the movement of the diaphragm resulting in venous flow stasis. The disruption of backflow from the lower body causes the appearance of edema in the legs. As a result, there was a decrease in backflow to the heart, cardiac output also decreases. To compensate for this reduction, the heart will work faster so that tachycardia and shortness occur in the patient.

In this patient there was an increase in LDH, where LDH is a tumor marker in dysgerminoma. While AFP, bHCG and Ca 125 are not specific for dysgerminoma, these markers are elevated during pregnancy, so the results cannot be followed for the patient's follow-up.

In this patient surgical staging was not performed because the patient's clinical complaint was severe. Viewed from the side of the pregnancy 25-26 weeks is a safe age to be operated operatively, but due to the patient's clinical condition and the suspicion of paraaortic KGB metastases that are difficult to access, it was decided that the administration of chemotherapy was using the BEP regimen. After chemotherapy the patient's complaints got better, according to the literature that dysgerminoma is very chemosensitive. ${ }^{20,21}$

At the age of 34-35 weeks of pregnancy the patient was admitted to the hospital with complaints of labor that can be caused by one of the side effects of chemotherapy that i.e. parturition premature.

Premature labor occurred, but for some reason obstetric patients cannot be born vaginal. SCTPP was performed and babies born with low birth weight 1600 grams under 50 percent of the ideal body weight curve of babies at the pregnancy age of 34-35 weeks, no congenital defects found in the baby, and A / S 7/8.

The patient was planned for surgical staging, but because the patient's condition was unstable due to uterine intraoperative bleeding, surgical staging was not performed.

Follow up to the patient after 1 month postpartum, from the patient's history there were no complaints, and no side effects were found from the chemotherapy agent. Physical examination was also not palpable, dry surgery wound, from USG examination found metastases to the uterus, and from CT scan results of abdominal found metastases to the par aortic and uterine nodes. In this patient there were 2 management options: 1 . Perform laparotomy again for surgical staging 2. Continue chemotherapy. In this patient, chemotherapy was chosen to be continued because clinically there was no worsening and the patient's response was good with 2 previous cycles of chemotherapy. The patient was given 4 cycles of chemotherapy with good response. The patient was recommended for routine 


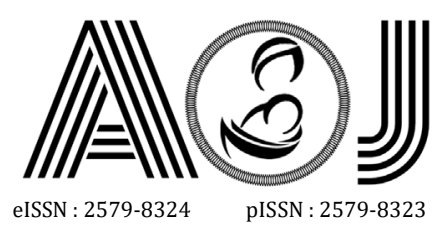

ANDALAS OBSTETRICS AND GYNECOLOGY JOURNAL

Alamat Korespondensi:

Ruang Redaksi Andalas Obstetrics and Gynecology Journal, Lantai 3 PPDS Obstetri dan Ginekologi Universitas Andalas, RSUP DR. M. Djamil Padang, Jl. Perintis Kemerdekaan Padang, Sumatera Barat 25127

http://jurnalobgin.fk.unand.ac.id/index.php/JOE

control of the first year every 3 months, the next 2 years every 6 months and up to 10 years every 1 year. Follow up included anamnesis, physical examination, ultrasound, tumor marker and CT scan. $8,22,23$

\section{CONCLUSION}

1. Inferior vena cava syndrome is a rare and fatal case, it can be caused by compression by the tumor dysgerminoma period or enlargement of the paraaortic KGB due to metastatic dysgerminoma

2. The diagnosis of dysgerminoma is from an anatomic pathology examination

3. Management of dysgerminoma is operative / surgical staging and administration of a 3-4 cycle chemotherapy regimen

4. BEP (Bleomycin-Etopuside-Cisplatin) chemotherapy regimens are safely administered in trimesters 2 and 3

5. Dysgerminoma has a good response to chemotherapy with a $96 \%$ survival rate.

\section{REFERENCES}

1. Marc Gewilig. Obstructions of the Inferior and Superior Vena Cava. VOWB, Belgium: p.669-73

2. Masayuki Takemori, Takaya Ichimura, Ryuichiro Nishimura, Kazuo Hasegawa. Ovaria Dysgerminoma with Massive Metastases to Paraaortic Lymph Nodes.2000. Gynecol Obstet Invest: 49: 211-13

3. Victor E Valdespino, Yazzmin Ballesteros, Montenegro, Maricruz Rivera Hernandjez, German Maytorena Cordova, Juan Landa Mejia, dkk. 2 Cases Dysgerminoma with Micrometastases in Lymph Nodes. 2018. Medcrave: Obstet Gynecol Int: 10(I) p.31-4

4. Chad M Michener. Editor: Warner K Huh. Ovarian Dysgerminomas. 2018. Medscape. Diakses tanggal 14 Februari 2019

5. Satoshi Tamauchi, Hiroaki Kijiyama, Masato Yoshihara, Yoshiki Ikeda, Nobuhisa Yoshikawa, Kimihiro Nishihino, dkk. Reproductive Outcomes of 105 Malignant Ovarian Germ Cell Tumor Survivors: a Multicenter Study. 2018. AJOG: p.385 e1-e7

6. William D. Tucker, Bracken Burns. Anatomy Abdomen Pelvis, Inferior Vena Cava. 2018. StatPearls Publishing:NCBI

7. Jonathan S Berek, Michael L Driedlander, Nevile F Hacker. Germ Cell and Nonepithelial Ovarian Cancer in Berek \& Hecker Gynecology Oncology Text Book.2015. Baltimore : Walters Kluwer : Chap.12 p. 530

8. Shinichi Komiyama. Safe dissection of High Paraaortic Lymph Nodes Superior to the Renal Vein in Ovarian, Primary Peritoneal, or Fallopian Tube Cancer by the " 


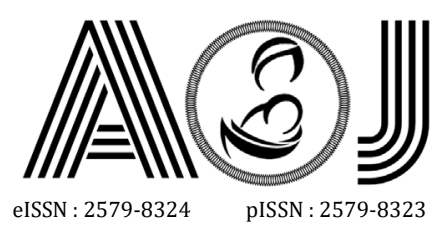

Ruang Redaksi Andalas Obstetrics and Gynecology Journal, Lantai 3 PPDS Obstetri dan Ginekologi Universitas Andalas, RSUP DR. M. Djamil Padang, Jl. Perintis Kemerdekaan Padang, Sumatera Barat 25127

Komiyama's Maneuver", a Modification of Kocher's Maneuver.2017. ScienceDirect Elsevier.Vol.145: p.407-8 https://doi.org/10.1016/j.ygyno.2017.02. 015

9. Osman Turkmen, Alper Karalok, Derman Basaran, Gunsu Comert Kimyon, Tolga Tasci, Isin Ureyen, dkk. Fertility- Sparing Surgery Should be the Standard Treatment in Patients with Malignant Ovarian Germ Cell Tumors. 2017. Journl of Adolescent and Young Adult Oncology. Vol: 00. Doi:10.1089/jayao.2016.0086

10. Mamta Gupta, Vandana Saini. Germ Cell Tumors and their Association with Pregnancy. 2018. INTECH:Chap 6: p. 12341.doi.org/10.5772/intechopen.7255 6

11. Michael Hubalek, Caecilia Smekal, Alan G Zeimet, Consolato Sergi, Christoph Brezinka, Elisabeth Mueller, dkk. Chemotherapeuitic of a Pregnant Patient with Ovarian Dysgerminoma. 2007. Arch Gynecol Obstet. 276: 179- 183 DOI 10.1007/s00404-0070328-2

12. Bender F Aldhafery. Ovarian Dysgerminoma in Two Sister. 2008. J Family Community. Med. 2008 Sep- Dec; 15(3): 127-131.

13. Tamara L Callahan, Aaron B Caughey. Ovarian \& Fallopian Tube Tumor in Obstetric \& Gynecology Textbook. 2018. Philadelpia: Walters Kluwer; Chap 30 p.1026-41

14. Ting Zhao, Yan Liu, Hongyuan Jiang, Hao Zhang aand Yuan lu. Management of Bilateral Malignant Ovararian Germ Cell Tumors: Experience of a single Institute. 2015. Molecular and Clinicak Oncology 5: 383-7

15. Jasmina Popovic, Sonja Trajkovic, Milan Trenkic, Aleksandra Aracki. Dysgerminoma and Pregnancy. 2017. DOI https://doi.org/10.2298/SARH16092307 4

16. I Nyoman, I Wayan Artana. Kehamilan dengan Kanker Ovarium Tipe Disgerminoa Stadium 1C. 2016. Universitas Udayana

17. Jana Dekrem, Kristel Van Calsteren. Efect of Fetal Exposureto Maternal Chemotherapy. 2013. Springer Inernational Publishing Switzerland. Doi 10.1007/s40272-013-0040-6

18. Yuanyuan Chen, Ying Luo, Cha Han, Wenyan Tian, Wen Yang, Yiengmei Wan,dkk. Ovarian Dysgerminoma in Pregnancy: a Case report and Literature Review. 2018. Jounal Cancer Biology \&Therapy.doi.org/10.1080/15384047.2 018.1450118

19. Mamta Gupta, Rita Jindal, Vandana Saini. An Incidental Finding of Bilateral Dysgerminoma During Caesarean Section: Dilemmas in Management. 2016.DOI:10.7860/JCDR/2016/20163.8 319

20. Yoon Kyung Lee, Chang Young Yoo, Guisera Lee, Dong Choon Park. Ovarian Dysgerminoma Associated with Pregnancy. 2011. Korean J Obest Gynecol 2011; 54(4);218-222 doi.10.5468/KJOG.2011.54.4.218

21. Nexhmi Hyseni, Sadik Llullaku, Hysni Jashari, Kaltrina Zhiti, Fjolla Hyseni, Fisnik Kurshumliu, dkk. Advanced Ovarian Dysgerminoma Infiltrating Both Ovaries and 


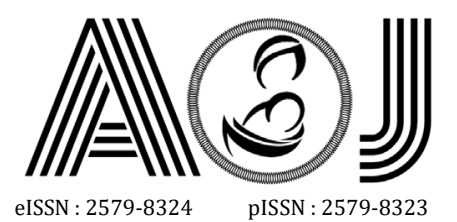

eISSN : 2579-832

Ruang Redaksi Andalas Obstetrics and Gynecology Journal, Lantai 3 PPDS Obstetri dan Ginekologi Universitas Andalas, RSUP DR. M. Djamil Padang, Jl. Perintis Kemerdekaan Padang, Sumatera Barat 25127

\section{Website:}

http://jurnalobgin.fk.unand.ac.id/index.php/JOE

Uterus in a 7-year-old Girl. 2014. Hindawi: vol. 2014, Articel ID910852.Doi.Org/10.1155/2014/91085 2

22. Ivani Juliarty Sitanggang. Dysgerminoma Ovarium pada anak perempuan 16 tahun. Denpasar.

23. Kafil Akhtar, Shamshad Ahmad, Amit Kumar, Noor Afshan. Dysgerminoma with Pregnancy and Viable Baby: A Case Report. 2011. Oman Medical Journal Vol.26 No.3 : 198-200 